\title{
Characterization of Rhizobial Bacteria Nodulating Astragalus corrugatus and Hippocrepis areolata in Tunisian Arid Soils
}

\author{
MOSBAH MAHDHI ${ }^{1}$, NADIA HOUIDHEG ${ }^{2}$, NEJI MAHMOUDI ${ }^{2}$, ABDELHAKIM MSAADEK ${ }^{2}$, \\ MOKHTAR REJILI ${ }^{2}$ and MOHAMED MARS ${ }^{2}$ \\ ${ }^{1}$ Center for Environmental Research and Studies, Jazan University, Jazan, Kingdom of Saudi Arabia \\ ${ }^{2}$ Research Unit Biodiversity and Valorization of Arid Areas, Bioressources (BVBAA), \\ Faculty of Sciences, Gabès University, Erriadh-Zrig, Gabès, Tunisia
}

Submitted 13 June 2015, revised 11 October 2015, accepted 11 February 2016

Abstract

Fifty seven bacterial isolates from root nodules of two spontaneous legumes (Astragalus corrugatus and Hippocrepis areolata) growing in the arid areas of Tunisia were characterized by phenotypic features, $16 \mathrm{~S}$ rDNA PCR-RFLP and 16S rRNA gene sequencing. Phenotypically, our results indicate that $A$. corrugatus and $H$. areolata isolates showed heterogenic responses to the different phenotypic features. All isolates were acid producers, fast growers and all of them used different compounds as sole carbon and nitrogen source. The majority of isolate grew at pHs between 6 and 9, at temperatures up to $40^{\circ} \mathrm{C}$ and tolerated $3 \% \mathrm{NaCl}$ concentrations. Phylogenetically, the new isolates were affiliated to four genera Sinorhizobium, Rhizobium, Mesorhizobium and Agrobacterium. About 73\% of the isolates were species within the genera Sinorhizobium and Rhizobium. The isolates which failed to nodulate their host plants of origin were associated to Agrobacterium genus (three isolates).

Ke y word s: 16S rDNA sequencing, arid areas, PCR-RFLP, phenotypic properties, rhizobial bacteria

\section{Introduction}

Rhizobia or "legume nodulating bacteria (LNB)" or "root nodule bacteria' (RNB)" are defined as nitrogenfixing bacteria that form nodules on legume plants. In the last few years, a large diversity of LNB has been revealed, which has caused deep changes in the taxonomy of these bacteria. Rhizobia currently consist of 98 species belonging to 13 different genera. The predominant symbionts for most legume species in habitats throughout the world are found in the $a$-class of Proteobacteria: Rhizobium, Azorhizobium, Ensifer (formerly Sinorhizobium), Mesorhizobium, Bradyrhizobium, Methylobacterium (Jaftha et al., 2002; Jourand et al., 2004), Devosia (Rivas et al., 2003), Shinella (Lin et al., 2008), Ochrobactrum (Trujillo et al., 2005; ZurdoPineiro et al., 2007), Phyllobacterium (Valverde et al., 2005; Mantelin et al., 2006) and Microvirga (Ardley etal., 2012). Moreover, about eight species within two genera of $\beta$-class of Proteobacteria - Burkholderia and Cupriavidus have been reported (Moulin et al., 2001; Chen et al., 2001; 2006; 2008; Klonowska et al., 2012). In addition, bacteria from $\gamma$-class of Proteobac- teria have also been reported (Benhizia et al., 2004; Muresu et al., 2008; Mahdhi et al., 2012). On the other hand, many Agrobacterium-like strains have been isolated from root nodules of different legumes species (Gurtler etal., 1991; Liu etal., 2005; Mahdhi et al., 2008), but all of them failed to nodulate their original plant hosts and until now no definitive explanation of the presence of these bacteria inside nodules could be demonstrated.

Legumes belonging to the genera Astragalus and Hippocrepis are distributed in northern Africa, southern Europe and East Asia. Several Astragalus species are used as herbal medicine and Hippocrepis species have a wide range of uses as minor crops including consumption, fodder, forage and land stabilization. Despite the high number of these legume species (3000 species for Astragalus and 20 for Hippocrepis), only few of them have been considered for their nitrogen symbiotic fixation. Previous studies reported that microsymbionts associated to root nodules of some Astragalus species belonged to Sinorhizobium, Rhizobium, Agrobacterium, Bradyrhizobium and Mesorhizobium (Zhang et al., 2000; Gao et al., 2001; 2004; Wei et al., 2003; Zhao et al., 2012;

\footnotetext{
* Corresponding author: M. Mahdhi, Center for Environmental Research and Studies, Jazan University, Jazan, Kingdom of Saudi Arabia; e-mail: mosbahtn@yahoo.fr
} 
Guerrouj et al., 2013; Gnat et al., 2014). Surprisingly, Muresu et al. (2008) reported that strains isolated from Hippocrepis unisiliquosa are identified as members of the genus Bacillus or as uncultured bacteria.

At Tunisia, Astragalus and Hippocrepis nitrogenfixing symbiotic associations are poorly documented (Zakhia et al., 2004; Mantelin etal., 2006). Previous research's reported that rhizobia associated to Astragalus glombiformis, Astragalus armatus, Astragalus corrugatus and Astragalus algerianus were assigned to the genus of Rhizobium and Phyllobacterium, and only one isolate from nodules Hippocrepis areolata was affiliated to the genus Sinorhizobium (Zakhia et al., 2004).

Considering the potential value of the Astragalus and Hippocrepis species in the arid regions of Tunisia and the little information available about the diversity of their root nodulating bacteria, the present paper aim to determine the taxonomic diversity of 57 bacterial collection isolated from root nodules of A.corrugatus and $H$. areolata by using polyphasic approach including phenotypic and PCR-RFLP analysis and 16S rRNA gene sequencing.

\section{Experimental}

Materials and Methods

Bacterial isolation and growth conditions. Fifty seven isolates and six reference strains (Table I) representing different rhizobial species belonging to Rhizobium, Sinorhizobium and Mesorhizobium were used in this study. Rhizobial bacteria were isolated from naturally occurring root nodules collected in four arid soils of Tunisia (Table I). For rhizobia isolation, healthy nodules dissected from roots were surface sterilized with ethanol (70\%) and sodium hypochlorite (2\%). Then nodules were separately crushed and the nodule juice was streaked on plates of yeast-mannitol agar (YMA) (Vincent, 1970) and incubated at $28^{\circ} \mathrm{C}$ for the isolation of the rhizobia. The obtained bacterial colonies were purified by being repeatedly streaked on the same medium. Pure isolates were stored with 25\% (wt/vol) glycerol at $-80^{\circ} \mathrm{C}$.

Nodulation test. To assess nodulation, seeds were surface-sterilized in $98 \%$ sulphuric acid for $30 \mathrm{~min}$ and germinated on $\mathrm{H}_{2} \mathrm{O}$-agar plates $(0.8 \%)$ at $25^{\circ} \mathrm{C}$. Seedlings were transferred into vermiculite, inoculated with individual isolates and grown in a growth chamber at $25^{\circ} \mathrm{C}$ with $12-16 \mathrm{~h}$ photoperiod. Nitrogen-free nutrient solution was used for plant watering (Vincent, 1970). Controls, not inoculated, were included. Four replicates were maintained for each treatment. Four weeks post inoculation, the plants were uprooted and the occurrence of nodulation in each plant was checked.
Phenotypic characterization. All isolates were initially tested for their phenotypic features. For bacterial growth, bacteria were cultivated in $50 \mathrm{ml}$ of YM broth into $250 \mathrm{ml}$ Erlenmeyer flasks and incubated in a gyratory shaker at $180 \mathrm{~g}$ and $28^{\circ} \mathrm{C}$. Growth was followed by measuring the optical density at $600 \mathrm{~nm}$ every $2 \mathrm{~h}$ and generation time of each isolate was deduced from the exponential phase of the growth curves.

Growth of the isolates at different temperatures (28, $\left.37,40,42,45^{\circ} \mathrm{C}\right)$, the ability to grow in the presence of different $\mathrm{NaCl}$ concentrations $(1,2,3,4,5 \%)$ and at different $\mathrm{pH}$ levels $(4,5,7,9,11)$ were determined by growth on supplemented YMA as described by Mohamed et al. (2000).

The modified-YMA medium (Somasegaran and Hoben, 1994) was used to investigate the ability of isolates to use carbohydrates ( $1 \%$ glucose, galactose, fructose and sucrose) and amino-acids (0.1\% L-proline, $\mathrm{L}$-arginine, L-tyrosine and L-leucine) as a sole carbon and nitrogen sources respectively. Production of acid or alkali was determined on YMA supplemented with $0 \pm 0025 \%$ (w/v) bromothymol blue as $\mathrm{pH}$ indicator. All phenotypic tests were performed in triplicate.

PCR amplification and RFLP analysis of $16 \mathrm{~S}$ rRNA gene. Total genomic DNA was extracted as described by Mhamdi et al. (2002). Primers fD1 and rD1 (Weisburg et al., 1991), were used for PCR amplification of 16S rRNA gene. PCR was carried out in Gen Amp PCR system 9700 (Applied Biosystems) in a $25 \mu \mathrm{l}$ containing template DNA extract as described previously by Mahdhi et al. (2012). PCR amplification was analyzed by horizontal $1 \%(\mathrm{w} / \mathrm{v})$ agarose gel electrophoresis stained with ethidium bromide. The amplified DNA fragments of 16S rRNA gene were digested with RsaI, Hinfl, HaeIII, CfoI, NdeII and MspI restriction enzymes (Promega products). The restriction patterns were checked by horizontal $4 \%$ (w/v) agarose gel electrophoresis stained with ethidium bromide.

Different 16S rDNA types were designed based upon the combined RFLP patterns obtained from the six enzymes, e.g. isolates is defined as a unique $16 \mathrm{~S}$ rDNA type if it has one band different from other isolates in the six digestions

Sequencing of 16S rRNA gene. Bacterial genomic DNA extracted according to Mhamdi et al. (2002) was used as templates. For five isolates $16 \mathrm{~S}$ rDNA gene chosen as representative of different $16 \mathrm{~S}$ rDNA types, were amplified using universal primers $\mathrm{fD} 1$ and $\mathrm{rD} 1$ as described above. The PCR products were purified and sequenced using the ABI PRISM BigDye Terminator cycle sequencing kit according to the manufacturer's protocol and analysed on an ABI PRISM 310 Genetic Analyzer (Applied Biosystems). Sequences were assembled using ChromasPro and were aligned with Clustal X. The acquired sequences were deposited 
Table I

New isolates and reference strains used in this study.

\begin{tabular}{|c|c|c|c|c|}
\hline Isolates & Site of origin & Host plants & $\begin{array}{c}\text { Nodulation } \\
\text { test }\end{array}$ & $\begin{array}{c}\text { 16SrDNA } \\
\text { type }\end{array}$ \\
\hline ACM1 & Menzel Habib & Astragalus corrugatus & - & $1^{\star}$ \\
\hline ACM2 & Menzel Habib & Astragalus corrugatus & $+(12)$ & $2 \dagger$ \\
\hline ACM3 & Menzel Habib & Astragalus corrugatus & $+(11)$ & $2 \dagger$ \\
\hline ACM4 & Menzel Habib & Astragalus corrugatus & $+(10)$ & $2 \dagger$ \\
\hline ACN1 & Nefta & Astragalus corrugatus & $+(15)$ & $3^{\phi}$ \\
\hline $\mathrm{ACN} 2$ & Nefta & Astragalus corrugatus & $+(14)$ & $3^{\phi}$ \\
\hline ACN3 & Nefta & Astragalus corrugatus & $+(11)$ & $3^{\phi}$ \\
\hline ACN4 & Nefta & Astragalus corrugatus & $+(11)$ & $3^{\phi}$ \\
\hline ACN5 & Nefta & Astragalus corrugatus & $+(10)$ & $2 \dagger$ \\
\hline ACN6 & Nefta & Astragalus corrugatus & $+(10)$ & $2 \dagger$ \\
\hline ACN7 & Nefta & Astragalus corrugatus & $+(10)$ & $2 \dagger$ \\
\hline ACN8 & Nefta & Astragalus corrugatus & $+(13)$ & $2 \dagger$ \\
\hline ACN9 & Nefta & Astragalus corrugatus & $+(15)$ & $2 \dagger$ \\
\hline ACN10 & Nefta & Astragalus corrugatus & - & $1^{*}$ \\
\hline ACN11 & Nefta & Astragalus corrugatus & $+(14)$ & $2 \dagger$ \\
\hline ACN12 & Nefta & Astragalus corrugatus & $+(14)$ & $3^{\phi}$ \\
\hline $\mathrm{ACN} 13$ & Nefta & Astragalus corrugatus & $+(13)$ & $3^{\phi}$ \\
\hline ACN14 & Nefta & Astragalus corrugatus & $+(11)$ & $2 \dagger$ \\
\hline ACN15 & Nefta & Astragalus corrugatus & $+(11)$ & $2 \dagger$ \\
\hline ACN16 & Nefta & Astragalus corrugatus & $+(14)$ & $3^{\phi}$ \\
\hline ACZ1 & Zarzis & Astragalus corrugatus & $+(13)$ & 4 丰 \\
\hline ACZ2 & Zarzis & Astragalus corrugatus & $+(15)$ & $4 \ddagger$ \\
\hline ACZal & Zárate & Astragalus corrugatus & $+(15)$ & $4 \ddagger$ \\
\hline $\mathrm{ACZa} 2$ & Zárate & Astragalus corrugatus & $+(15)$ & $4 \ddagger$ \\
\hline $\mathrm{ACZa} 3$ & Zárate & Astragalus corrugatus & $+(12)$ & $4 \ddagger$ \\
\hline HBM1 & Menzel Habib & Hippocrepis areolata & $+(12)$ & $3^{\phi}$ \\
\hline HBM2 & Menzel Habib & Hippocrepis areolata & $+(13)$ & $3^{\phi}$ \\
\hline HBM3 & Menzel Habib & Hippocrepis areolata & $+(14)$ & $3^{\phi}$ \\
\hline HBM4 & Menzel Habib & Hippocrepis areolata & $+(11)$ & $3^{\phi}$ \\
\hline HBM5 & Menzel Habib & Hippocrepis areolata & $+(10)$ & $3^{\phi}$ \\
\hline HBM6 & Menzel Habib & Hippocrepis areolata & $+(10)$ & $3^{\phi}$ \\
\hline HBM7 & Menzel Habib & Hippocrepis areolata & $+(11)$ & $3^{\phi}$ \\
\hline HBM8 & Menzel Habib & Hippocrepis areolata & $+(12)$ & $3^{\phi}$ \\
\hline HBM9 & Menzel Habib & Hippocrepis areolata & $+(13)$ & $3^{\phi}$ \\
\hline HBN1 & Nefta & Hippocrepis areolata & $+(14)$ & $3^{\phi}$ \\
\hline HBN2 & Nefta & Hippocrepis areolata & $+(12)$ & $3^{\phi}$ \\
\hline $\mathrm{HBN} 3$ & Nefta & Hippocrepis areolata & $+(11)$ & $3^{\phi}$ \\
\hline HBN4 & Nefta & Hippocrepis areolata & $+(10)$ & $5 \dagger$ \\
\hline HBN5 & Nefta & Hippocrepis areolata & $+(11)$ & $3^{\phi}$ \\
\hline HBN6 & Nefta & Hippocrepis areolata & $+(12)$ & $5 \dagger$ \\
\hline HBN7 & Nefta & Hippocrepis areolata & $+(12)$ & $3^{\phi}$ \\
\hline HBN8 & Nefta & Hippocrepis areolata & $+(12)$ & $5 \dagger$ \\
\hline HBN9 & Nefta & Hippocrepis areolata & $+(13)$ & $3^{\phi}$ \\
\hline HBN10 & Nefta & Hippocrepis areolata & $+(10)$ & $5 \dagger$ \\
\hline HBZ1 & Zarzis & Hippocrepis areolata & $+(10)$ & $2 \dagger$ \\
\hline HBZ2 & Zarzis & Hippocrepis areolata & $+(15)$ & $2 \dagger$ \\
\hline HBZ3 & Zarzis & Hippocrepis areolata & $+(14)$ & $3^{\phi}$ \\
\hline
\end{tabular}


Table I

New isolates and reference strains used in this study.

\begin{tabular}{|c|c|c|c|c|}
\hline Isolates & Site of origin & Host plants & $\begin{array}{c}\text { Nodulation } \\
\text { test }\end{array}$ & $\begin{array}{c}\text { 16SrDNA } \\
\text { type }\end{array}$ \\
\hline HBZ4 & Zarzis & Hippocrepis areolata & $+(13)$ & $2 \dagger$ \\
\hline HBZ5 & Zarzis & Hippocrepis areolata & $+(12)$ & $2 \dagger$ \\
\hline HBZ6 & Zarzis & Hippocrepis areolata & $+(14)$ & $2 \dagger$ \\
\hline HBZ7 & Zarzis & Hippocrepis areolata & $+(14)$ & $2 \dagger$ \\
\hline HBZ8 & Zarzis & Hippocrepis areolata & $+(13)$ & $5 \dagger$ \\
\hline HBZ9 & Zarzis & Hippocrepis areolata & $+(12)$ & $5 \dagger$ \\
\hline HBZ10 & Zarzis & Hippocrepis areolata & $+(11)$ & $5 \dagger$ \\
\hline HBZ11 & Zarzis & Hippocrepis areolata & - & $1^{*}$ \\
\hline HBZ12 & Zarzis & Hippocrepis areolata & $+(10)$ & $2 \dagger$ \\
\hline HBZ13 & Zarzis & Hippocrepis areolata & $+(15)$ & $2 \dagger$ \\
\hline R. mongolense STM246 ${ }^{\mathrm{T}}=\mathrm{LMG} 1941^{\mathrm{T}}$ & Mongolia, China & Medicagoruthenica & $\mathrm{Nt}$ & 6 \\
\hline R. galegae $\mathrm{HMBI} 540^{\mathrm{T}}=\mathrm{LMG} 6214^{\mathrm{T}}$ & Finland & Galegae orientalis & $\mathrm{Nt}$ & 7 \\
\hline M. loti ORS664=LMG6125 ${ }^{\mathrm{T}}$ & New Zealand & Lotus tenuis & $\mathrm{Nt}$ & 8 \\
\hline M. mediterraneum ORS2739 $=\mathrm{LMG} 17148^{\mathrm{T}}$ & Spain & Cicer arietinum & $\mathrm{Nt}$ & 9 \\
\hline S. meliloti ORS665 $5^{\mathrm{T}}=\mathrm{LMG} 133^{\mathrm{T}}$ & Virginia, USA & Medicagosativa & $\mathrm{Nt}$ & 3 \\
\hline B. japonicum NZP5549 ${ }^{\mathrm{T}}=\mathrm{LMG} 6138^{\mathrm{T}}$ & Japon & Glycine max & $\mathrm{Nt}$ & 10 \\
\hline
\end{tabular}

Note: STM: collection du laboratoire des Symbioses tropicales et méditerranéennes; HAMBI: Culture Collection of the Department of Microbiology, University of Helsinki, Helsinki, Finland; LMG: Collection of Bacteria of the Laboratorium voor Microbiologie, Universiteit Ghent, Belgium; NZP: Culture Collection of the Department for Scientific and Industrial Research, Biochemistry Division, Palmerston North, New Zealand; ORS: Collection, Laboratoire commun de Microbiologie, BP 1386, Dakar, Senegal; ${ }^{\mathrm{T}}$ type strain. ${ }^{*}$ : isolates grouped in genus Agrobacterium; $\uparrow$ : isolates grouped in genus Rhizobium; ${ }^{*}$ : isolates grouped in genus Sinorhizobium, $\ddagger$ : isolates grouped in genus Mesorhizobium. + Positive test, - no nodulation. Numbers in parentheses indicate the number of nodules per plant, Nt: not tested

in the GenBank database and were analysed for homologies to related sequences obtained from GenBank. The phylogenetic analyses were performed using mega 3.1 software (Kumar et al., 2001). A neighbour-joining tree was constructed using Kimura twoparameter model (Kimura, 1980) of and support of internal branches was assessed using 1000 bootstrap replications. The GenBank accession numbers for the $16 \mathrm{~S}$ rRNA gene sequences reported in this paper are KR108303 (ACN5), KR108304 (HBN4), KR108300 (ACM1), KR108301 (ACN1) and KR108302 (ACZ1).

\section{Results}

Nodulation test and phenotypic characterisation. A nodulation test was performed for all isolates. Result showed that only two A. corrugatus isolates (ACM1 and ACN10) and one H. areolata isolate (HBZ11) affiliated to Agrobacterium by $16 \mathrm{~S}$ rRNA gene sequencing analysis (see below) failed to nodulate their host plant of origin. The other isolates formed ten to fifteen nodules per plantlet after four weeks post-inoculation (Table I).

Phenotypically, (Table II) all isolates were acid producers, fast growers (Generation times $<6 \mathrm{~h}$ ). Five A. corrugatus isolates (described by the analysis of $16 \mathrm{~S}$
rRNA sequences as Mesorhizobium have a generation time between 4 and $6 \mathrm{~h}$. All tested isolates used all tested compounds as sole carbon and nitrogen sources and were able to grow at $\mathrm{pHs}$ between 6 and 9, but none of them could grow at pHs 4 and 11 .

The majority of the isolates grew at 28,37 and $40^{\circ} \mathrm{C}$. Only two isolates (ACN1 and ACN4) continued to grow at $42^{\circ} \mathrm{C}$, but not at $45^{\circ} \mathrm{C}$. Most of the tested isolates tolerated $\mathrm{NaCl}$ concentrations from 1 to $3 \%$. Three A. corrugatus isolates (ACN1, ACN4, and ACN13) and one $H$. areolata isolate (HBZ1) continued to grow in $4 \%$ $\mathrm{NaCl}$ and none of them tolerated $5 \% \mathrm{NaCl}$.

PCR-RFLP analysis of $16 S$ rRNA gene. The new isolates of $16 \mathrm{~S}$ ribosomal DNA and reference strains was PCR-amplified and a single band of the expected size of approximately $1500 \mathrm{bp}$ was produced. PCR products were digested with six restriction enzymes RsaI, Hinfl, HaeIII, CfoI, NdeII and MspI. Ten 16S rDNA types were distinguished among the 57 isolates and the six reference strains. Each $16 \mathrm{~S}$ rDNA type comprised 1 to 23 isolates (Table I). Five rDNA types were identified among the new isolates. Types 1, 2, 3 of $16 \mathrm{~S}$ rDNA included new isolates originating from both $A$. corrugatus and $H$. areolata microsymbionts. The type 4 and 5 of $16 \mathrm{~S}$ rDNA contained only $A$. corrugatus and $H$. areolata isolates respectively. Type 3 of $16 \mathrm{~S}$ rDNA consisted of 
Table II

Phenotypic characteristics of the isolates

\begin{tabular}{|c|c|c|c|c|c|}
\hline \multicolumn{2}{|l|}{ Characteristics } & $\begin{array}{c}\text { Sinorhizobium } \\
\text { isolates }\end{array}$ & $\begin{array}{l}\text { Rhizobium } \\
\text { isolates }\end{array}$ & $\begin{array}{c}\text { Mesorhizobium } \\
\text { isolates }\end{array}$ & $\begin{array}{c}\text { Agrobacterium } \\
\text { isolates }\end{array}$ \\
\hline \multicolumn{2}{|l|}{ Number of isolates } & 23 & 26 & 5 & 3 \\
\hline \multirow[t]{2}{*}{ Generation time } & $\mathrm{G}<4 \mathrm{~h}$ & + & + & - & + \\
\hline & $4 \leq \mathrm{G}<6$ & - & - & + & - \\
\hline \multirow[t]{3}{*}{ Growth at pH } & 4 & - & - & - & - \\
\hline & 9 & + & + & + & + \\
\hline & 11 & - & - & - & - \\
\hline \multicolumn{2}{|l|}{ Acid production } & + & + & + & + \\
\hline \multicolumn{2}{|l|}{ Alkali production } & - & - & - & - \\
\hline \multirow[t]{4}{*}{$\mathrm{NaCl}$ tolerance } & $2 \%$ & + & + & + & + \\
\hline & $3 \%$ & + & $+(20)$ & + & - \\
\hline & $4 \%$ & $+(3)$ & $+(1)$ & - & - \\
\hline & $5 \%$ & - & - & - & - \\
\hline \multirow[t]{4}{*}{ Utilisation of sugars } & glucose & + & + & + & + \\
\hline & galactose & + & + & + & + \\
\hline & fructose & + & + & + & + \\
\hline & sucrose & + & + & + & + \\
\hline \multirow[t]{4}{*}{ Utilisation of amino acids } & L-arginine & + & + & + & + \\
\hline & L-proline & + & + & + & + \\
\hline & L-leucine & + & + & + & + \\
\hline & L-tyrosine & + & + & + & + \\
\hline \multirow[t]{3}{*}{ Growth at temperature } & $40^{\circ} \mathrm{C}$ & + & $+(24)$ & $+(4)$ & - \\
\hline & $42^{\circ} \mathrm{C}$ & $+(2)$ & - & - & - \\
\hline & $45^{\circ} \mathrm{C}$ & - & - & - & - \\
\hline
\end{tabular}

Note: (+) positive growth/ present; (-) no growth/absent;

Number in parentheses indicate the number of positive isolates of the total number of isolates tested

both new isolates and a reference strain (Sinorhizobium meliloti LMG6133 ${ }^{\mathrm{T}}$ ).

Sequencing of $16 \mathrm{~S}$ rDNA. A total of five A. corrugatus and $H$. areolata isolates representing the five different $16 \mathrm{~S}$ rDNA types were selected to undergo $16 \mathrm{~S}$ rDNA gene sequencing. New A.corrugatus and $H$. areolata strains exhibited 99-100\% 16S rDNA sequence similarity with reference species already described in GenBank. In the reconstructed phylogenetic tree (Fig. 1), strain ACZ1 (Representative of 16S rDNA type 4) was phylogenetically related to Mesorhizobium temperatum CCNWSX0012-2 and to Mesorhizobium sp. LAC831. The two isolates ACN5 and HBN4, representative of $16 \mathrm{~S}$ rDNA types 2 and 5 respectively, were grouped in Rhizobium branch; with ACN5 strain was associated to Rhizobium sp. STM 394, while HBN4 strain was affiliated related to Rhizobium sp. STM 4037. The sequences of $16 \mathrm{~S}$ rDNA of the strain ACN1 was closely related to the $16 \mathrm{~S}$ rDNA sequences of S. meliloti LMG6133 ${ }^{\mathrm{T}}$ and Sinorhizobium sp. STM4038, while the strain ACM1 was phylogenetically related to Agrobacterium tumefaciens 2002000903 and Agrobacterium sp. STM4035.

\section{Discussion}

Currently, in the rhizobia taxonomy the polyphasic approach, based on phenotypic and genomic criteria is used (Graham et al., 1991; Vandamme et al., 1996; Małek and Sajnaga, 1999). Among the phenotypic features characteristic related to the microorganism ecological niches are considered as the most interesting. In the present studies a collection of 57 isolates was obtained from A.corrugatus and $H$. areolata root nodules covering four regions of Tunisia and characterized by a polyphasic approach including phenotypic features, PCR-RFLP of 16S rDNA and 16S rDNA sequence analysis. All isolates, except ACM1, ACN10 and HBZ11, re-induce nodules in their host plant. The three non-re-nodulating strains can be considered as opportunistic endophytes as already proposed (Zakhia et al., 2006; Mahdhi et al., 2007; 2012).

Phenotypically (Table II) our results indicate that A. corrugatus and H. areolata isolates showed heterogenic responses to the different phenotypic features. This heterogeneity may contribute the nodulation of 


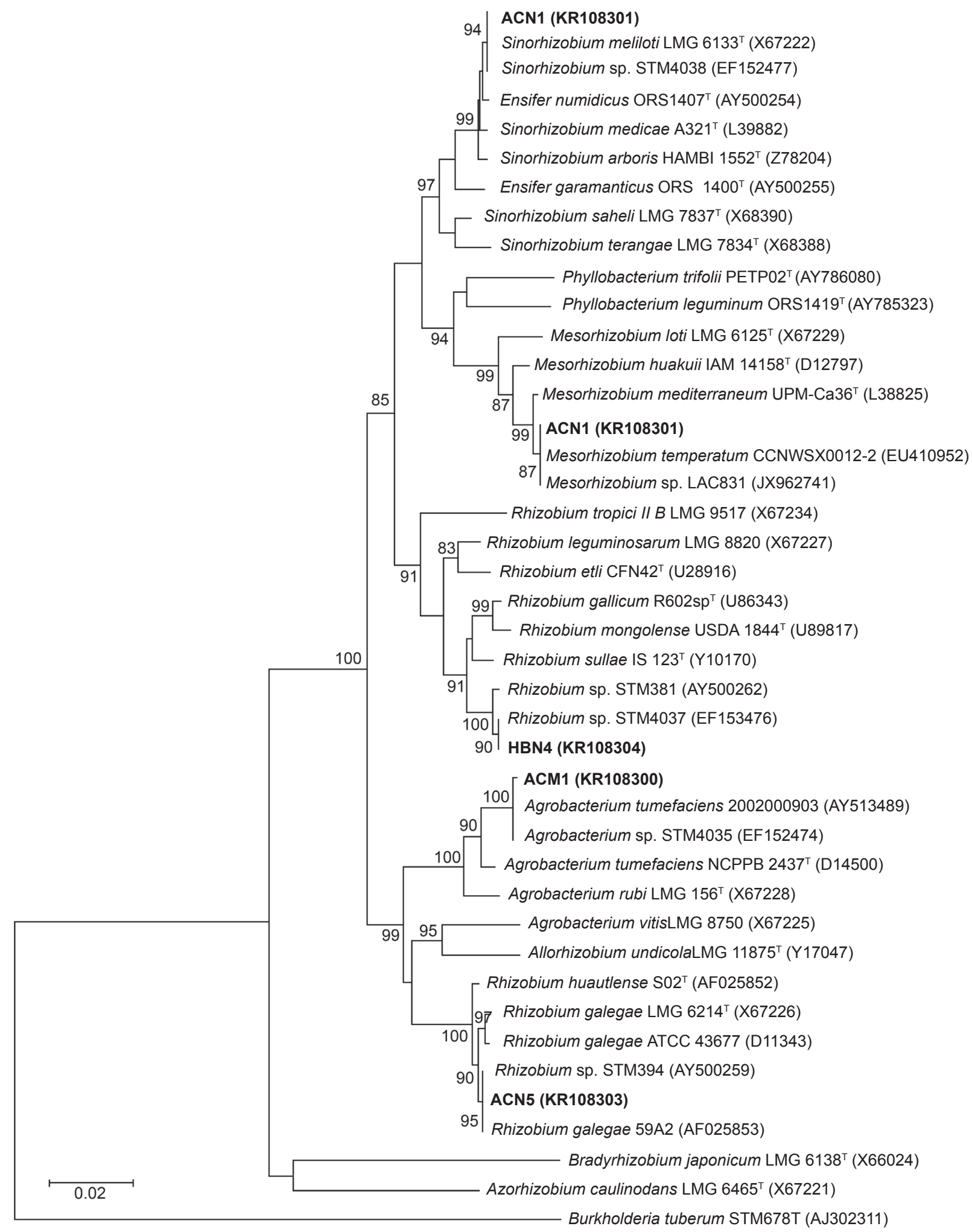

Fig. 1. 16S rRNA gene sequence-based dendrogram obtained by neighbor-joining method showing the phylogenetic positions of A. corrugatus and H. areolata isolates. Only significant bootstraps (>80\%) are shown (1000 replications).

Sequence accession numbers are listed in parentheses.

legumes in different conditions (Wei et al., 2008). All new isolates are acid producers, fast growers (Generation times $<6$ h) like Rhizobium, Sinorhizobium and Mesorhizobiun species (Małek and Sajnaga, 1999). All tested isolates are able to use all tested compounds as sole carbon and nitrogen sources. Similar results were reported by Guerrouj et al. (2013) for rhizobia nodulating A. glombiformis in Eastern Morocco. This ability to use a wide range of carbon sources could be beneficial for the bacterial life cycle in the soil and may be related 
to their high competitiveness in a natural environment. Elkan (1992) reported that carbohydrate sources could be used to differentiate fast-growing rhizobia from the slow-growing bradyrhizobia.

As for salinity, temperature and $\mathrm{pH}$ tolerance, our results showed that most of the isolates are able to grow at $3 \% \mathrm{NaCl}$, at $\mathrm{pHs}$ between 6 and 9 and at high temperature $\left(40^{\circ} \mathrm{C}\right)$, except of two of them which were continued to grow at $42^{\circ} \mathrm{C}$. These results corroborate our earlier reports on the root nodule bacteria isolated from wild legumes in Tunisia (Mahdhi et al., 2007; 2008; Rejili et al., 2009; Fterich et al., 2011). Similarly, Guerrouj et al. (2013) reported that rhizobial strains associated to A.glombiformis are tolerant to $342 \mathrm{mM}$ $\mathrm{NaCl}$ and $40^{\circ} \mathrm{C}$ in Eastern Morocco. In China, Wei et al. (2003) reported that some rhizobial strains nodulating Astragalus species tolerate only $2 \% \mathrm{NaCl}$. The capacity of new isolates to tolerate high temperatures and high $\mathrm{NaCl}$ concentrations could be considered a specific adaptation to high soil temperatures and salinity in arid regions as described by Karanja and Wood (1988).

By using the comparative 16S rRNA gene sequence analysis, the new isolates were grouped on the phylogram in the Sinorhizobium, Rhizobium, Mesorhizobium and Agrobacterium genera; with $73 \%$ of the new isolates are species within the genera Sinorhizobium and Rhizobium as are many other indigenous legume symbionts from Tunisia (Zakhia et al., 2004; Ben Romdhane et al., 2005; Mahdhi et al., 2008). By 16S rRNA gene sequencing of isolates ACN5 (16S rDNA type 2), HBN4 (16S rDNA type 5) and ACN1 (16S rDNA type 3) are closely related to Tunisian legume nodulating bacteria belonging to Rhizobium sp. STM 394, Rhizobium sp. STM 4037 and Sinorhizobium sp. STM4038 which were isolated from Astragalus cruciatus and Argyrolobium uniflorum growing on the same Tunisian soils (Zakhia et al., 2004; Mahdhi et al., 2008). So, it would now be interesting to test the cross-nodulation capacity of our new isolates on A. cruciatus and A. uniflorum legumes.

It has been previously reported that $A$. corrugatus is nodulated by strains belonging to the genera Rhizobium, Sinorhizobium, Brdyrhizobium, Mesorhizobium, Agrobacterium and Phyllobacterium (Wei et al., 2003; Gao et al., 2004; Zakhia etal., 2004; Mantelin et al., 2006; Guerrouj et al., 2013; Zheng et al., 2013; Gnat etal., 2014). Our results thus confirm the previous studies showing the large diversity of $A$. corrugatus rhizobia that belong to Rhizobium, Sinorhizobium, Mesorhizobium and Agrobacterium. However, no Phyllobacterium and Bradyrhizobium were recovered in our results. Others studies (Guerrouj et al., 2013; Gnat et al., 2014) showed that Astragalus glycyphyllos in Poland and A. glombiformis in Morocco were nodulated by rhizobial bacteria belonging only to the genus Mesorhizobium. Among our collection only five A. cor- rugatus isolates (16S rDNA type 5) were phylogenetically grouped in Mesorhizobium branch, closely related to M. temperatum CCNWSX0012-2 and to Mesorhizobium sp. LAC831 nodulating Lotus creticus from arid regions of Tunisia (Rejili et al., 2009; 2012; 2013). This diversity of rhizobia nodulating Astragalus species may be in relation with climatic and edaphic conditions. Our study confirms that the Astragalus species nodulated by several rhizobial genomspecies can be qualified as promiscuous and that their rhizobia have very diverse genomic and symbiotic gene backgrounds (Zhao et al., 2008; Gnat et al., 2014)

Until now, nodulation of Hippocrepis species has been poorly documented (Zakhia et al., 2004; Muresu et al., 2008). In addition, only two strains were included in these studies. In our collection, $H$. areolata isolates are identified as Rhizobium, Sinorhizobium and Agrobacterium genera.

Several studies have reported the presence of Agrobacterium strains in nodules of some legumes (de Lajudie et al., 1999; Gao et al., 2001; Liu et al., 2005; Mhamdi et al., 2005; Mrabet et al., 2006), but all them failed to nodulate their original host plants. Here we isolated three Agrobacterim isolates (16S rDNA type 1) that also failed to nodulate their host plants in vitro. The sequences of $16 \mathrm{~S}$ rDNA of one isolated Agrobacterium isolate (ACM1) is closely related to the $16 \mathrm{~S}$ rRNA gene sequence of Agrobacterium sp. STM4035, which was isolated by Mahdhi et al. (2008) from the root nodules of the pastoral legume A. uniflorum.

In conclusion, our study is the first report on the characterisation of A.corrugatus and H. areolata in Tunisia. Our investigation showed that LNB originating from nodules of these legumes was genetically diverse and affiliated with Rhizobium, Sinorhizobium, Mesorhizobium and Agrobacterium. Most of A. corrugatus and $H$. areolata isolates were related to previously described LNB in Tunisian soils. However, rhizobia from other locations that were not covered in this study should be investigated to provide further information about the diversity of bacteria nodulating these legumes in Tunisia

\section{Acknowledgements \\ This work was supported by the Ministry of High Education and Research Development-Tunisia. The authors thank Dr Philippe de} Lajudie, who kindly provided the reference strains

\section{Literature}

Ardley J.K., M.A. Parker, S.E. De Meyer, R.D. Trengove, G.W. O'Hara, W.G. Reeve, R.J. Yates, M.J. Dilworth, A. Willems and J.G. Howieson. 2012. Microvirga lupini sp. nov., Microvirga lotononidis sp. nov., and Microvirga zambiensis sp. nov. are 
Alphaproteobacterial root nodule bacteria that specifically nodulate and fix nitrogen with geographically and taxonomically separate legume hosts. Int. J. Syst. Evol. Microbiol. 62: 2579-2588.

Ben Romdhane S., H. Nasr, R. Samba-Mbaye, M. Neyra and M. Ghorbal. 2005. Diversity of Acacia tortilis rhizobia revealed by PCR/ RFLP on crushed root nodules in Tunisia. Ann. Microbiol. 55: 249-258.

Benhizia Y., H. Benhizia, A. Benguedouar, R. Muresu, A. Giacomini and A. Squartini. 2004. Gammaproteobacteria can nodulate legumes of the genus Hedysarum. Syst. Appl. Microbiol. 27: 462-468. Chen W.M., S. Laevens, T.M. Lee, T. Coenye, P. De Vos, M. Mergeay and P. Vandamme. 2001. Ralstonia taiwanensis sp. nov., isolated from root nodules of Mimosa species and sputum of a cystic fibrosis patient. Int. J. Syst. Evol. Microbiol. 51: 1729-1735.

Chen W.M., E.K. James, T. Coenye, J.H. Chou, E. Barrios, S.M. De Faria, G.N. Elliott, S.Y. Sheu, J.I. Sprent and P. Vandamme. 2006. Burkholderia mimosarum sp. nov., isolated from root nodules of Mimosa spp. from Taiwan and South America. Int. J. Syst. Evol. Microbiol. 56: 1847-1851.

Chen W.M., S.M. De Faria, J.H. Chou, E.K. James, G.N. Elliott, J.I. Sprent, C. Bontemps, J.P. Young and P. Vandamme. 2008. Burkholderia sabiae sp. nov., isolated from root nodules of Mimosa caesalpiniifolia. Int. J. Syst. Evol. Microbiol. 58: 2174-2179.

de Lajudie P., A. Willems, G. Nick, S.H. Mohamed, U. Torck, R. Coopman, A. Filali-Maltouf, K. Kersters, B. Dreyfus, K. Lindström and others. 1999. Agrobacterium bv. 1 strains isolated from nodules of tropical legumes. Syst. Appl. Microbiol. 22: 119-132. Elkan G.H. 1992. Taxonomy of the rhizobia. Can. J. Microbiol. 38: $446-450$.

Fterich A., M. Mahdhi, M.A. Caviedes, E. Pajuelo, R. Rivas, I.D. Rodriguez-Llorente and M. Mars. 2011. Characterization of root-nodulating bacteria associated to Prosopis farcta growing in the arid regions of Tunisia. Arch. Microbiol. 193: 385-397.

Gao J.L., Z.D. Terefework, W.X. Chen and K. Lindström. 2001. Genetic diversity of rhizobia isolated from Astragalus adsurgens growing in different geographical regions of China. J. Biotechnol. 91: 155-168.

Gao J.L., S.L. Turner, F.L. Kan E.T Wang, Z.Y. Tan, Y.H. Qiu, J. Gu, Z. Terefework, J.P.W. Young, K. Lindström and others. 2004. Mesorhizobium septentrionale sp. nov. and $M$. temperatum sp. nov., isolated from Astragalus adsurgens growing in the northern regions of China. Int. J. Syst. Evol. Microbiol. 54: 2003-2012.

Gnat S., M. Wójcik, S. Wdowiak-Wróbel, M. Kalita, A. Ptaszyńska and W. Małek. 2014. Phenotypic characterization of Astragalus glycyphyllos symbionts and their phylogeny based on the 16S rDNA sequences and RFLP of $16 \mathrm{~S}$ rRNA gene. Antonie Van Leeuwenhoek. 105: 1033-1048.

Graham P.H., M.J. Sadowsky, H.H. Keiser, Y.M. Barnet, R.S. Bradley, J.E. Cooper, D.J. De Ley, B.D.W. Jarvis, E.B. Roslycky, B.W. Strijdom and others. 1991. Proposed minimal standards for the description of new genera and species of root and stem-nodulating bacteria. Int. J. Syst. Bacteriol. 41: 582-587.

Guerrouj K., E. Pe'rez-Valera, R. Chahboune, H. Abdelmoumen, E.J. Bedmar M.M. El Idrissi. 2013. Identification of the rhizobial symbiont of Astragalus glombiformis in Eastern Morocco as Mesorhizobium camelthorni. Antonie van Leeuwenhoek. 104: 187-198.

Gurtler V., V.A. Wilson and B.C. Mayall. 1991. Classification of medically important clostridia using restriction endonuclease site differences of PCR-amplified 16S rDNA. J. Gen. Microbiol. 137: 2673-2679.

Jaftha J.B., B.W. Strijdom and P.L. Steyn. 2002 Characterization of pigmented methylotrophic bacteria which nodulate Lotononis bainesii. Syst. Appl. Microbiol. 25: 440-449.

Jourand M., E. Giraud, G. Béna, A. Sy, A. Willems, M. Gillis, B. Dreyfus and P. De Lajudie. 2004. Methylobacterium nodulans sp. nov., for a group of aerobic, facultatively methylotrophic, legume root-nodule forming and nitrogen-fixing bacteria. Int. J. Syst. Evol. Microbiol. 54: 2269-2273.

Karanja, N.K. and M. Wood. 1988. Selecting Rhizobium phaseoli strains for use with beans (phaseolus vulgaris L.) in Kenya: tolerance of high temperature and antibiotic resistance. Plant Soil. 112: 15-22. Kimura M. 1980. A simple method for estimating evolutionary rates of base substitutions through comparative studies of nucleotide sequences. J. Mol. Evol. 16: 111-120.

Klonowska A., C. Chaintreuil, P. Tisseyre1, L. Miche, R. Melkonian, M. Ducousso, G. Laguerre, B. Brunel and L. Moulin. 2012 Biodiversity of Mimosa pudica rhizobial symbionts (Cupriavidus taiwanensis, Rhizobium mesoamericanum) in New Caledonia and their adaptation to heavy metal-rich soils. FEMS Microbiol. Ecol. 81: 618-635.

Kumar S., K. Tamura, I.B. Jakobsen and M. Nei. 2001. MEGA2 Molecular Evolutionary Genetics Analysis software. Bioinformatics. 17: $1244-1245$.

Lin D.X., E.T. Wang, H. Tang, T.X. Han, Y.R. He, S.H. Guan and W.X. Chen. 2008. Shinella kummerowiae sp. nov., a symbiotic bacterium isolated from root nodules of the herbal legume Kummerowia stipulacea. Int. J. Syst. Evol. Microbiol. 58: 1409-1413.

Liu J., E.T. Wang and W.X Chen. 2005. Diverse rhizobia associated with woody legumes Wisteria sinensis, Cercis. Syst. Appl. Microbiol. 28: 465-477.

Mahdhi M., A. Nzoué, F. Gueye, C. Merabet, P. de Lajudie and M. Mars. 2007. Phenotypic and genotypic diversity of Genista saharae microsymbionts from the infra-arid region of Tunisia. Lett. Appl. Microbiol. 54: 604-609.

Mahdhi M., P. de Lajudie and M. Mars. 2008. Phylogenetic and symbiotic characterization of rhizobial bacteria nodulating Argyrolobium uniflorum in Tunisian arid soils. Can. J. Microbiol. 54: 209-217

Mahdhi M., A. Fterich, M. Rejili, I.D. Rodriguez-Llorente and M. Mars. 2012. Legume-Nodulating Bacteria (LNB) from three pasture legumes (Vicia sativa, Trigonella maritima and Hedysarum spinosissimum) in Tunisia. Ann. Microbiol. 62: 61-68.

Małek W. and E. Sajnaga. 1999. Current taxonomy of the rhizobia. Acta. Microbiol. Pol. 48: 109-122.

Mantelin S., M. Fischer-Le Saux, F. Zakhia, G. Béna, S. Bonneau, H. Jeder, P. De Lajudie and J.C. Cleyret-Marel. 2006. Emended description of the genus Phyllobacterium and description of four novel species associated with plant roots: Phyllobacterium bourgogense sp. nov., Phyllobacterium ifriqiyense sp. nov., Phyllobacterium leguminum sp. nov. and Phyllobacterium brassicacearum sp. nov. Int J. Syst. Evol. Microbiol. 56: 827-839.

Mhamdi R., G. Laguerre, M.E. Aouani, M. Mars and N. Amarger. 2002. Different species and symbiotic genotypes of field rhizobia can nodulate Phaseolus vulgaris in Tunisian soils. FEMS Microbiol. Ecol. 41: 77-84.

Mhamdi R., M. Mrabet, G. Laguerre, R. Tiwari and M.E. Aouani 2005. Colonization of Phaseolus vulgaris nodules by Agrobacteriumlike strains. Can. J. Microbiol. 51: 105-111.

Mohamed S.H., A. Smouni, M. Neyra, D. Kharchaf and A. FilaliMaltouf. 2000. Phenotypic characteristics of root-nodulating bacteria isolated from Acacia spp. grown in Libya. Plant Soil. 224: 171-183. Moulin L., A. Munive, B. Dreyfus and C. Boivin-Masson. 2001 Nodulation of legumes by members of the beta-subclass of Proteobacteria. Nature 411: 948-950.

Mrabet M., B. Mnasri, S. Ben Romdhane, G. Laguerre, M.E. Aouani and R. Mhamdi. 2006. Agrobacterium strains isolated from root nodules of common bean specifically reduce nodulation by Rhizobium gallicum. FEMS Microbiol. Ecol. 56: 304-309.

Muresu R., E. Polone, L. Sulas, B. Baldan, A. Tondello, G. Delogu, P. Cappuccinelli, S. Alberghini, Y. Benhizia, H. Benhizia and 
others. 2008. Coexistence of predominantly nonculturable rhizobia with diverse, endophytic bacterial taxa within nodules of wild legumes. FEMS Microbiol. Ecol. 63: 383-400.

Rejili M., M.J. Lorite, M. Mahdhi, J.S. Pinilla, A. Ferchichi and M. Mars. 2009. Genetic diversity of rhizobial populations recovered from three Lotus species cultivated in the infra-arid Tunisian Soils. Progress in Natural Science 19: 1079-1087.

Rejii M., M. Mahdhi, A. Fterich, S. Dhaoui, I. Guefrachi, R. Abdeddayem and M. Mars. 2012. Symbiotic nitrogen fixation of wild legumes in Tunisia: Soil fertility dynamics, field nodulation and nodules effectiveness. Agriculture, Ecosystems and Environment 157: 60-69.

Rejii M., M. Mahdhi, J.A. Domínguez-Núñez and M. Mars. 2013. The phenotypic, phylogenetic and symbiotic characterization of rhizobia nodulating Lotus sp. in Tunisian arid soils. Ann. Microbiol. 64: 355-362.

Rivas R., A. Willems, N.S. Subba-Rao, P.F. Mateos, F.B. Dazzo, R.M. Kroppenstedt, E. Martinez-Molina, M. Gillis and E. Velázquez. 2003. Description of Devosia neptuniae sp. nov. that nodulates and fixes nitrogen in symbiosis with Neptunia natans, an aquatic legume from India. Syst. Appl. Microbiol. 26: 47-53.

Somasegaran P. and H.J. Hoben. 1994. Handbook of rhizobia, p. 450. In: Methods in legume-rhizobium technology. Springer New York.

Trujillo E.M., A. Willems, A. Abril, A.M. Planchuelo, R. Rivas, D. Ludena, P.F. Mateos, E. Martinez-Molina and E. Velazquez. 2005. Nodulation of Lupinus albus by strains of Ochrobactrum lupine sp. nov. Appl. Environ. Microbiol. 71: 1318-1327.

Valverde A., E. Velázquez, F. Fernández-Santos, N. Vizcaíno R. Rivas, P.F. Mateos, E. Martínez-Molina, J.M. Igual and A. Willems. 2005. Phyllobacterium trifolii sp. nov., nodulating Trifolium and Lupinus in Spanish soils. Int. J. Syst. Evol. Microbiol. 55: 1985-1989. Vandamme P., B. Pot, M. Gillis, P. de Vos, K. Kersters and J. Swing. 1996. Polyphasic taxonomy, a consensus approach to bacterial systematics. Microbiol. Rev. 60:407-438.

Vincent J.M. 1970. A manual for the practical study of root nodule bacteria. IBP Handbook, No. 15. Blackwell, Oxford

Wei G.H., Z.Y. Tan, M.E. Zhu, E.T. Wang, S.Z. Han and W.X Chen. 2003. Characterization of rhizobia isolated from legume species within the genera Astragalus and Lespedeza grown in the Loess
Plateau of China and description of Rhizobium loessense sp. nov. Int. J. Syst. Evol. Microbiol. 53: 1575-1583.

Wei G.H., Z.X. Zhang, C. Chen, W.M. Chen and W.T. Ju. 2008. Phenotypic and genetic diversity of rhizobia isolated from nodules of the legume genera Astragalus, Lespedeza and Hedysarum in northwestern China. Microbiol. Res. 163: 651-662.

Weisburg W.G., S.M. Barns, D.A. Pelletior and D.J. Lane. 1991 $16 \mathrm{~S}$ ribosomal DNA amplification for phylogenetic study. J. Bacteriol. 173: 697-703.

Zakhia F., H. Jeder, O. Domergue, A. Willems, J.C. Cleyet-Marel, M. Gillis, B. Dreyfus and P. De Lajudie. 2004. Characterisation of legume nodulating bacteria (LNB) in arid regions of Tunisia. Syst. Appl. Microbiol. 27: 380-395.

Zakhia F., H. Jeder, A. Willems, M. Gillis, B. Dreyfus and P. De Lajudie. 2006. Diverse bacteria associated with root nodules of spontaneous legumes in Tunisia and first report for nifH-like gene within the genera Microbacterium and Starkeya. Microbial Ecol. 51: 375-393.

Zhang X.X., S.L. Turner, X.W. Gao, H.J. Yang, F. Debelle, G.P. Yang, J. Denarie, J.P.W. Young and F.D. Li. 2000. The common nodulation genes of Astragalus sinicus rhizobia are conserved despite chromosomal diversity. Appl. Environ. Microbiol. 66: 2988-2995.

Zhao C.T., E.T. Wang, W.F. Chen and W.X. Chen. 2008. Diverse genomic species and evidences of symbiotic gene lateral transfer detected among the rhizobia associated with Astragalus species grown in the temperate regions of China FEMS Microbiol. Lett. 286: 263-273

Zhao C.T., E.T. Wang, Y.M. Zhang, W.F. Chen, X.H. Sui, W.X. Chen, H.C. Liu and X.X. Zhang. 2012. Mesorhizobium silamurunense sp. nov., isolated from root nodules of Astragalus species Int. J. Syst. Evol. Microbiol. 62: 2180-2186.

Zheng W.T., Y. Li, R. Wang, X.H. Sui, X.X. Zhang, J.J. Zhang, E.T. Wang and W.X. Chen. 2013. Mesorhizobium qingshengii sp. nov., isolated from effective nodules of Astragalus sinicus Int. J. Syst. Evol. Microbiol. 63: 2002-2007.

Zurdo-Piñero J.L., R. Rivas, M.E. Trujillo, J.A. Vizcaíno Carrasco, A. Chamber Palomares, P.F. Mateos, E. Martínez-Molina and

E. Velázquez. 2007. Ochrobactrum cytisi sp. nov., isolated from nodules of Cytisus scoparius in Spain. Int. J. Syst. Evol. Microbiol. 57: 784-788. 
